\title{
Consumer Purchase Behavior in Cellular Service Sector of Pakistan
}

\author{
Zohaib Ahmad and Junaid Ahmad \\ Shaheed Zulfikar Ali Bhutto Institute of Science \& Technology, Islamabad \\ University of Lahore, Islamabad
}

\begin{abstract}
This study reflects the latest buying behavior of people residing in Islamabad and Rawalpindi in cellular service sector which has been dominating the business world of Pakistan in today's era. As the purchasing behavior in any part of the world is reliant mainly on quality, price, promotions, and social factors, this study too focuses on these factors so as to understand and comprehend the reasons behind the purchase behavior of people in Pakistan with respect to the cellular service sector.
\end{abstract}

\section{Introduction}

Technology reached to different countries at different age and time. In Pakistan, technology was introduced in the late 1980's which changed the course of the business world as well as the entire system of communication, transactional procedures, business environment and the like. With the advent of technology in Pakistan, telecommunication sector grew radically. According to Pakistan Telecommunication Authority (PTA), a regulating body, telecommunication sector in Pakistan has witnessed a $150 \%$ increase in continuous growth rate from the year 2003 to 2006. The progress in the industry is remarkable as mobile telecom operators have now introduced mobile banking models in Pakistan such as Easy Paisa and UBL Omni. Mobile telecom operators contribute a great deal in revenue generation in telecommunication industry. In Pakistan, there are five mobile telecom service providers; Mobilink, Telenor, Ufone, Warid and Zong. All of these mobile telecom operators have had growth in the market over the years, however their market share has varied in different years. In 2009-2010, Mobilink had the highest market share which was 32.5\% which dropped in 2010-2011 to 30.7\%. Likewise, Ufone's market share decreased from $19.7 \%$ to $18.9 \%$ from $2009-2010$ to $2010-2011$. The market share of another renowned mobile telecom operator; Warid also decreased from 17\% to 16\% from 2009-2010 to 2010-2011. Unlike Mobilink, Ufone and Warid, the market share of Telenor increased from $24.0 \%$ to $24.4 \%$ from 2009-2010 to 2010-2011. Similarly, the market share of Zong increased from $6.8 \%$ to $10.0 \%$ in the same years (Pakistan Telecommunication Authority, 2011). Such varying market share within three years is quite questionable which is why it is of prime importance to understand the purchase behavior of customers which leads the mobile telecom operators to have increasing or decreasing trends in their market share over the years. It has been observed that the mobile subscribers have increased from 33 million to 120 million from 2005 to 2012 (Pakistan Telecommunication Authority , 2012). In the arena of antagonistic marketing campaigns, cut-throat competition, special discounts and irresistible offers of call packages, SMS bundles, low international call rates, the telecom mobile operators have managed to reach 11.2 million subscribers by FY2012.

PTA conducts periodical quality of service (QoS) survey throughout the country so that the set quality benchmarks are followed and if not then legal actions, penalties and Show Cause be taken against cellular service providers. PTA is to ensure customer satisfaction at all costs especially in terms of QoS offered by the service providers. Hence, it has been persistently monitoring the performance of the five cellular service providers of Pakistan. QoS surveys and Drive Tests; conducted by NEMO QoS automated monitoring equipment which provides computerized results, are used to monitor their performance. As of 2011, it was seen that only Telenor, Ufone and CMPak Zong achieved the desired level of Network Downtime; less than 1\%, while Mobilink and Warid had a downtime of more than $1 \%$. It was also seen that the success rate of delivery must be $99 \%$ in the SMS category of QoS, however the survey showed Mobilink, Telenor, CMPak Zong were just below the desired threshold value while Warid and Ufone went below 95\% (Pakistan Telecommunication Authority, 2011).

The availability of different mobile telecom operators has become the reason for extreme confusion amongst people. Consumers' taste, preferences and purchase behavior changes with time due to many factors; some have been mentioned. The varying purchase behavior of people living in Pakistan must be analyzed so as to assist the business environment and economy of Pakistan with respect to the cellular service sector. Products and services have gone through different era's; production era, product era, sales orientation, marketing, and now relationship orientation era. Consumers' knowledge has increased and now they are well aware of their needs and wants more than ever which is why it's empirical to analyze their behavior according to their values and culture that prevails in the modern globalized world. In the 1980s and 1990s consumer choice became one 
of the fundamental stimulus behind privatization, focusing more on the quality of service delivered to the customers (Watson, Viney, \& Schomaker, 2002). But from the analysis of the facts, the concept of understanding consumers and their behavior is not the $19^{\text {th }}$ century phenomenon, it's been the focus of many companies even in the 1970s.

\subsection{Significance of the Study}

This study emphasizes on the purchase behavior of people located in Islamabad and Rawalpindi. Due to the emerging competition and accessibility of mobile telecom operators, it has become imperative to analyze and determine the factors that affect the customer purchase behavior. This will further make an impact on the market share and sustainability of particular mobile service providers and it will provide them with guidelines to follow to improve their services. The study includes factors such as quality, price, promotional activities and social factors such as the influence of friends and family.

\subsection{Problem Statement}

Pakistan is one of the developing countries of the world and its cellular service sector has seen significant growth. People living in Pakistan have a wide-variety of choice when it comes to selecting a particular mobile service provider. However, it is not very evident as to what motivates them to select their service provider. Thus, this study was directed to identify the dominating factors that affect the purchase behavior of mobile consumers in Pakistan.

\subsection{Objectives}

- To identify the major determinants of purchase behavior in the cellular service sector of Pakistan

- Identification of relationships of independent variables with dependent variable through empirical testing

- $\quad$ To identify which determinant affects the purchase behavior the most in Islamabad/Rawalpindi

\section{Literature Review}

Hitherto, the first phone purchased by people was at the age of 18 , however this has changed now and children aged 14-15 own mobile phones. Certainly, price and properties are the most influential factors and motives that drive people to buy a new mobile phone whereas price, audibility and friends' mobile operators were the prime factors in choosing a mobile operator for their phones (Pakola, Pietila, Svento, \& Karjaluoto, 2001).

According to Schiffman \& Kanuk (2009), consumer behavior deals with the search for purchasing, using, evaluating, and disposing of products and services that they think will satisfy their needs and wants in the limited resources that they acquire. Certainly, consumers play an empirical role in sustaining the marketing dynamics. Henry Ford easily produced the same colored car for almost ten years and there still was demand in the market because the consumption was there. The same cannot be done in today's modern era. This is because of the changing buying trends and increased competition in the market.

Comprehending consumer behavior is a fully developed field these days. It varies according to countries, industries, and even societies as well as or families. Hoyer \& MacInnis (2009) give us an apt definition of consumer behavior in their book; consumer behavior deals with goods, services, activities, people, ideas, and experiences. It is stated that from buying a necessity good such as a shampoo or a soap, into buying a luxury good like a massage chair of the renowned brand Osim, the purchase behavior of consumers vary and are accordingly reflected. Members of the same family have different behavior with respect to activities, goods, experiences, goods etc. All the processes that are involved in mental as well as physical acts of individuals, groups, or organizations and relate to acquiring, using or even disposing of the goods and services to satisfy needs is the study of consumer behavior (Hawkins, Mothersbaugh, \& Mookerjee, 2010).

Furaiji, Łatuszyńska, \& Wawrzyniak (2012) cover up all the dynamics that have direct and indirect influence on consumer preferences in the market of electric appliances. Their study emphasized on the relationship between several independent variables like cultural, social, personal, psychological, and marketing mix factors with consumer behavior. They categorized consumer behavior as extensive, routine and limited. The study also includes the decision-making process often discussed by authors when consumer behavior is the topic under consideration.

Usage of Smartphones has increased tremendously from 33\% of Canadian cell phone users in March 2011 to 48\% in March 2012. It has also been found that growth in the use of Smartphones is not only limited to a certain age group but its usage is spreading across all age groups. Almost half of the cell phone users have a data plan so that they can use the internet wherever they are (Quorus Consulting Group Inc. , 2012).

Kausar, Qureshi, Shehzad, \& Hasan (2012) provide us with the most valuable source of understanding the cellular service industry of Pakistan and how the consumers switch from one service provider to another. It 
recognizes the shift patterns of consumers through analyzing inconvenience, price, and core service failures that have been taken as the independent variables. The findings of this study give us a discernment as to how price and core services' failure ascertains to become the cause behind changing consumer behaviors in the cellular service sector of Pakistan.

Quality is one of the imperative foundations of what drives consumers to purchase a certain product. Measuring service quality is a challenge as it concerns the perceptions of consumers but it is possible. According to Nelson (1970) quality of service has great effects upon the entire structure of the market of consumer goods but economists have been interested in the determinants of monopoly power and one of the major determinants of it is consumer behavior in different industries.

Consumers take into account the efficiency of service transaction at all times. While, technical quality is allied to technical industry standards that must be followed by enterprises not only to survive but also to make sure that after meeting these standards they may introduce an element of differentiation in their service, functional quality is related to how the service is effectively delivered to the consumers (Oodan, et al., 1997).

Aydin \& Ozer (2005) conducted a study in Turkey which focuses on the relationship between perceived service quality, perceived switching cost, corporate image, trust and customer loyalty in mobile telecommunication sector. According to path analysis test, it has been revealed that all of the factors have a positive effect on customer loyalty which helps to retain customers in the short-run as well as in the long run.

It has been observed that many studies related to service quality and quality attributes deal with different approaches. The theory of attractive quality states that quality attributes can be classified into five categories; 'attractive quality', 'one-dimensional quality', 'indifferent quality', 'must-be quality' and 'reversed quality'. (Witell \& Lofgren, 2007). According to Witell \& Lofgren (2007), different approaches; five-level Kano Questionnaire, three-level Kano Questionnaire, direct classification and dual-importance grid, have different results. They may not be same and consistent.

It has been extensively conferred that quality criteria for generation $\mathrm{X}$ and $\mathrm{Y}$ are exceptionally contrasting. According to Kueh \& Voon (2007), there is high service expectation in generation Y especially in consumers living in Asia. They expect speedy and reliable service. Also, they expect service employees to be considerate, caring, and competent.

Negi (2009) conducted a research in Ethiopia to find out the perceived service quality of mobile telecommunications and its impact on consumers. The study revealed that more than half of the respondents (52.7\%) perceived the overall service quality of the Ethiopian Telecommunication Corporation to be below average while one third of the respondents (28\%) thought the overall quality was average, and only about one-fifth of the respondents (19.3\%) believed the overall service quality to be above average. The research also included SERVQUAL test to analyze the gap between consumer's expectations and actual service delivery. The dimension of network aspects maintained the widest gap rendering the fact that customers' expectations are not being met efficiently and competently.

A study conducted in 2010 reflects certain dimensions of perceived quality of cellular mobile telephone operators in Pakistan have a positive effect on perceptions of consumers. The study also concludes that SERVQUAL is a reliable instrument which can be used to assess the gap between customer expectation and experience in telecommunication industry of Pakistan. The gap, in the study, between customer expectation and experience was measured through SERVQUAL which was developed in the mid 1980's by Zeithaml, Parasuraman and Berry. The dimensions in the study consist of tangible, reliability, responsiveness, assurance, convenience, empathy and network quality. It has been seen that the dimensions discussed in the study have a positive and substantial on the perception of service quality of mobile phone users (Khan, 2010).

Santish, Kumar, Naveen, \& Jeevantham (2011) conducted a study in India about switching consumer behaviors in cellular service provider. It was focused on Chennai and the study concluded that call rates play a focal role in switching the service provider. Network coverage, value added services, customer care and advertisement play significant roles too but the importance of these factors varies. According to the study, the most preferred mobile service provider was Airtel, then comes BSNL, followed by Reliance, Aircel, Vodafone, Uninor, Tata Docomo, and the least preferred was Tata Indicom. The study provides an understanding of how consumers' perception and the actual quality of the network affect the buying behavior of consumers. It was seen that $47 \%$ of consumers were likely to switch to another mobile service operator if they don't get their expected quality of service that they are paying for.

According to Oracle - ATG Web Commerce (2011) pricing inclines to be a bigger influence for older consumers; $75 \%$ of consumers aged 55 and above and 73\% of those aged 35-54 said pricing plans and the overall cost was one of the three biggest factors for them when choosing a mobile provider. By comparison, 67 percent of those aged 18 to 34 cited pricing and cost. However, this survey's results limit only to the population of the United States of America.

A study conducted in Bangladesh revealed that for users of mobile services, the price is extremely important to $21 \%$ and very important to $23 \%$. It was seen that the consumers in Bangladesh were highly 
satisfied with their mobile service operators and out of the three success factors; brand image, price and customer service, consumers focused more on brand image (Ashaduzzaman, Sohel Ahmed, \& Khan, 2011).

According to Rajput, Kalhoro, \& Wasif (2012), the price of any product or service determines the buying behavior and intentions of customers. In Pakistan, it has been seen that customers prefer cheaper prices instead of high quality of products. This is because of low income levels of people living in Pakistan and also because of several other alternatives to a single product they are able to find the desired product at a cheaper price. There is an association between social influence, price, economy and beliefs to understand this specific mentality of customers.

Advertisements have two major effects on consumers; it becomes as the basis of learning new information about a brand, and it creates the brand image. Also, there is a dynamic model of consumer learning and experience which results in a certain behavior; purchase behavior. It has been seen that consumption of a product and exposure to advertisement lead to customer retention if quality and experience match the expectations of consumers (Ackerberg, 1998).

Advertising affects consumers through cognitive aspects; senses, perception, attention, memory, reasoning, language, etc. Advertisements help with customer retention and keep customers' attention intact. Along with cognitive aspects there are emotional and behavioral aspects as well that are affected as a result of good or bad adverts and promotions (Jakštienè, Susnienè, \& Narbutas, 2008).

Due to numerous number of service brands, consumers tend to get confused as to what brand should they choose, which brand satisfies them best and what are the alternatives. Confusion leads to inefficient choices no matter which industry it is. (Snider, 1993). The impact of word of mouth and dimensions like trust and satisfaction is essential in understanding consumer behavior (Walsh \& Mitchel, 2010) because when consumers compare two or more intricate products and get confused from the vague information they find, this possibly will lead to choice deferral (Dhar, 1997).

According to Hadjiphanis (2011), promotional tools especially television is still the most significant medium of advertisements. One of the factors that determine purchase behavior is advertisements and their impact. It influences consumers to purchase a product even if they don't want to purchase it at first. The study also revealed that other mediums of advertisements such as print media, newspaper, and the like are mostly ignored by customers because they are less attractive. Hence, televisions remain ahead of all the other mediums of advertisements and clearly cannot be ignored by customers.

Dadzie \& Mensah (2011) focus on Ghanian customers, in West Africa stating that four factors determine the brand preference of consumers with reference to mobile phone service operators, namely; promotion, price and availability of product, attractive packaging and product quality. Also, other attributes were included in the questionnaire to find out consumer preferences in Cape Coast Metropolis in Ghania. It was found that the source of information consumers gets about mobile service operators is either through print media, electronic or word of mouth. Television and friends and family members were most preferred sources of information which means that consumers in Ghania chose their mobile operators on the basis of promotional advertisements as well as word-of-mouth.

With respect to social and cultural values of youth residing in Pakistan, a study revealed that even though advertisements and packages, especially late night packages and unlimited SMS packages, play a negative role on the social values of Pakistani youth, youth ignores the negative aspect and still prefers the network that gives them the best offers (Shah et al., 2012). In 2012, Pakistan Telecommunication Authority ordered termination of late night mobile packages in order to counter the distressing social norms and values of the country (The Express Tribune, 2012).

Jung \& Kau (2004) focus on one of the many factors that affect consumer behavior. They mention as to how the three ethnic groups in Singapore and each have different behavior due to varied cultural dimensions. The finding highlights on individualism and collectivism as to how family or reference groups have an impact on the behavior of consumers in Malaysia. It also touches three other cultural dimensions; uncertainty avoidance, masculinity and power distance.

A research was conducted in Rajhastan, India. It was seen that the most important factors that influence the behavior of consumers of mobile services are call tariffs, network coverage, value added services, family members, friends, and advertisements. Also it was seen that consumers prefer prepaid packages more than postpaid packages (Rajpurohit \& Vasita, 2011).

According to Kaapand (2012), in the northern region of Namibia consumers' selection of mobile telecommunications service providers is based on some critical factors such as overall service quality, free calls and SMS, network capability, low rate changes, network innovativeness, network reliability, promotions with discounts etc. With these critical factors a prominent and perhaps a dominating factor exists; social factors. People choose those mobile operators that are already being used by their friends and family members. However, in this study it was concluded that celebrity promotional activities, special mobile number and high profile customers were least influential factors in considering which mobile operator one should choose. 
All of these variables have been used in this study to determine their influence and impact on consumer buying behavior has been thoroughly understood by literature that these specific variables are of utmost importance and are significant in analyzing the purchase behavior of consumers in the cellular service sector. The characteristics of consumers in Pakistan and these variables match in many aspects. Thus, they have been chosen so as to have appropriate and correct results of this study.

\subsection{Quality}

Researchers have been extensively studying the concept of service quality for a decade and it has been understood that service quality is not as simple to evaluate as quality of products. Schiffman \& Kanuk (2009) states that quality is one of the determinants of consumer behavior; it affects the purchase behavior of consumers. Therefore, quality has been chosen as one of the variables for this study to analyze the purchase behavior of consumers availing cellular services from different service providers of Pakistan. The dimensions used to assess quality of different service providers are connectivity, stability of the network, customer service, and expectation of the consumers.

\section{$2.2 \quad$ Price}

The literature proves the fact that price is an essential factor that determines consumer purchase behavior. Pakola, Pietila, Svento, \& Karjaluoto (2001) state that price affects the purchase behavior of people who want to buy new services especially focusing on the telecom sector. To aid this study price has been made a variable which includes expectation of prices offered by service providers and different discounts.

\subsection{Promotions}

The literature provides us with bounteous proofs of advertisements, word of mouth and other promotional activities as fundamental factors that have a direct or indirect effect on consumer purchase behavior. Thus, in order to have a valid and in-depth research about the relevant study area, this variable has been chosen.

\subsection{Social Factors}

Most of the studies related to cellular service provider and consumer behavior state that reference groups such as friends and family have an impact on consumer purchase behavior. Jung \& Kau (2004) and Kaapand (2012) both researchers found out that specifically in choosing mobile operators, consumers take the influence of their friends and family. Hence, it is one of the variables of this study.

\section{5}

Theoretical Framework

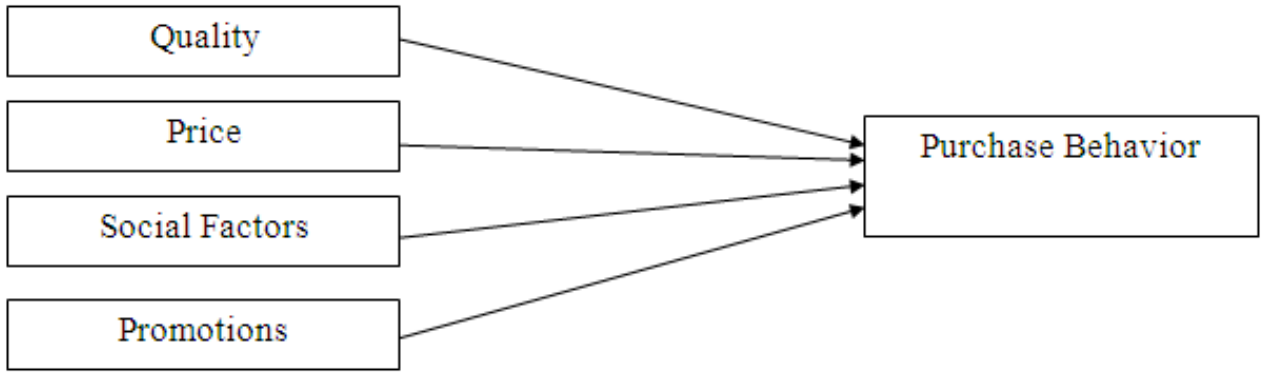

\subsection{Hypothesis}

H1: Quality has a positive impact on purchase behavior

H2: Price has a positive impact on purchase behavior

H3: Promotions have a positive impact on purchase behavior

H4: Social factors have a positive impact on purchase behavior

\section{Research Design}

The research model for this study is similar to that of Paulrajan \& Rajkumar (2011). It has been modified according to the culture and the nature of the research. As the emphasis of this study was to evaluate consumer behavior with respect to the cellular service sector of Pakistan, quantitative methodology was used. According to Johnson \& Christensen (2008), a quantitative methodology deals with the expansion and testing of hypothesis and the construction of models and theories that explain behavior. The focus of this study was to test the assumptions that certain variables have an impact on consumer buying behavior. In order to collect data, a questionnaire was designed. Questions were mainly adapted from previous researches carried out. There are many variables and dynamics to determine the purchase behavior of consumers in the cellular service sector, however only five variables have been chosen so as to inquire and understand the consumer behavior in Pakistan 
with respect to cellular services. These variables are quality, price, promotions, and social factors.

\subsection{Purpose of Study}

Research studies are of three types; exploratory, descriptive and hypothesis testing. Exploratory study is conducted especially when not much has been researched about a specific situation or condition. Whereas descriptive study deals with the ability to describe the characteristics of certain variables of the study. Hypothesis testing engages in the explanation of certain relationships or establish differences among groups or factors (Sekaran \& Bougie, 2010). This study is based on hypothesis testing and it moves around the impacts of independent variables on the dependent variable. As consumer behavior, preferences and their choices are hard to assess and determine the factors that drive consumers to behave in a particular way, this study is being conducted in order to see if quality, price, promotions, and social factors have an impact on consumer behavior in Pakistan's cellular service sector.

\subsection{Type of Investigation}

In the domain of research study, there are two types of investigation that are carried out by researchers; causal investigation and correlational investigation. Causal study is concerned with the cause and effect of variables that may or may not trigger their causative effects towards the commission or omission of a particular action. On the other hand, correlational study focuses on the interlinking and relational bondage between the selected independent and dependant variables (Sekaran \& Bougie, 2010). This study carried out the latter dogma towards the exploration of the relational factors between our selected dependent variable and independent variables to figure out how they compel and propel each other to their increment and decrement.

\subsection{Extent of Interference}

The general trends practiced towards research conduction involve minimal, moderate and excessive interference in the internal environment of the subject being researched by the researcher himself. Minimal interference is practiced for correlation studies where the researcher need not disrupt the normal flow of work in the workplace. On the contrary, moderate and excessive interferences are practiced in case of cause and effect studies where the researcher changes or control the normal work flow in the workplace to understand the cause and effect of variables (Sekaran \& Bougie, 2010). This study has minimal interference as only administered questionnaires were filled by respondents and the need to change the settings of a workplace or disrupt the routine workflow did not exist.

\subsection{Unit of Analysis}

The unit of analysis states to the level of accumulation of the data collected (Sekaran \& Bougie, 2010). Different researches have different unit of analysis due to their nature of the study and subject. Unit of analysis could be individuals, groups, dyads, organizations, divisions, industry or countries. For this study, data are collected from each individual who uses a mobile phone and has chosen a mobile operator of Pakistan.

\subsection{Data Collection Method}

400 questionnaires were floated while 263 responses were collected with a response rate of $65 \%$. Questionnaires were floated online as well as in different educational institutions, different organizations, and were self-administered.

\subsection{Time Horizon}

The data were gathered just once, over a period of days and weeks. It is a cross-sectional studied not a longitudinal one.

\subsection{Instrument Development}

A questionnaire was adopted and was used as a research instrument for this study. 40 questions including demographics were modified so as to match the distinctive environmental elements and features of telecommunication industry of Pakistan. However, during pilot testing, 4 questions were deleted so as to increase the reliability of the instrument. Five points Likert rating scale ranging from Strongly Agree (5) to Strongly Disagree (1) was used in the study. The question for each variable were adapted from Paulrajan \& Rajkumar (2011), Johnson \& Sirikit (2002), Xihao, Yang, \& Lee (2007), and Choi \& Kim (2007).

\subsection{Measurement}

Demographics have been collected using 4 items; Age, Gender, Profession, and Education Level. Independent variables; Quality was measured using 7 items, Price was measured using 4 items, Promotions was measured with 5 items, and Social Factors with 4 items. The dependent variable, Purchase Behavior was measured using 6 items respectively. 


\section{Data Analysis}

Under this chapter, the validity of the developed instrument was carried out. For statistical analysis, IBM Software SPSS 20 was used. The tools used for statistical analysis were mean, standard deviation, correlation and regression.

\subsection{Validity}

In order to be certain about the research instrument as well as the data collected, validity is checked. For this study, face validity and content validity were checked for confirmation of the instrument.

\subsubsection{Face Validity of Instrument}

Researchers determine whether or not their instrument is valid enough to measure what is intended to measure and this is done by taking the validity of the instrument at face value. In order to validate the instrument, academicians, professionals and potential respondents were shown the questionnaire to thoroughly review and analyze the content. Content that was unfit and may have caused issues in the future was deleted or modified.

\subsubsection{Content Validity of Instrument}

The content of the questionnaire was thoroughly checked and matched with the theoretical framework. Three questions were deleted after analyzing the content so as to make sure that the instrument is valid.

\section{2}

\begin{tabular}{lll}
$\begin{array}{l}\text { Reliability of Instrument } \\
\text { Table 1 } \\
\text { Reliability of variables }\end{array}$ & \\
\hline Constructs & Number of items & Cronbach's alpha \\
\hline Quality & 5 & 0.86 \\
Price & 3 & 0.85 \\
Promotions & 5 & 0.92 \\
Social Factors & 4 & 0.79 \\
Purchase Behavior & 6 & 0.74 \\
\hline
\end{tabular}

To test the reliability the instrument, IBM SPSS software was used so as to compute Cronbach's Alpha concerning all the variables of the study; quality, price, promotions, social factors, and purchase behavior. According to Nunnally (1978), Cronbach's Alpha coefficient must be greater than 0.7. Hinton et al. (2004) have suggested four types of values fluctuate from excellent to low reliability, which include excellent reliability (0.90 and above), high reliability (0.70-0.90), moderate reliability (0.50-0.70) and low reliability but is accepted (0.50 and below). Furthermore, Bowling (2009) suggests that Cronbach's Alpha greater than 0.9 is excellent, greater than 0.8 is being good, greater than 0.7 is acceptable, more than 0.6 is questionable, greater than 0.5 is poor and less than 0.5 is unacceptable. The computed Cronbach's Alpha coefficients under this study, for each independent variable were, Quality: 0.86, Price: 0.85, Promotions: 0.92, Social Factors: 0.79, and for the dependent variable, Purchase Behavior, the Cronbach's Alpha coefficient was 0.74 .

\subsection{Demographics}

In this research study, the total number of participants was 263 out of which $140(53 \%)$ were males and $123(47 \%)$ were females. The age group varies from 18 to 60. From the age group of 18-25, the respondents were $189(72 \%)$, there were $32(12 \%)$ respondents from the age group of 26-30. Similarly, the age group of $31-40$ consisted of $25(10 \%)$ respondents. From 40 above, there were $17(6 \%)$ respondents in total. The study revealed that the education level of 10 respondents was up till matriculation, while 99 respondents were undergraduates, 86 respondents were graduates, and 56 were post-graduates while 12 did not mention their education level.

Mobilink has the biggest market-share in Pakistan's cellular service industry. However, according to our study, only 19 respondents falling in the age group of 18-25 were using Mobilink while 6 respondents were falling in the age group of 26-30 and similarly in the age group of 31-40, 6 respondents were users of Mobilink. Ufone is the most popular mobile service provider amongst the youth as our study shows that 98 respondents were from the age group of 18-25. Similarly, 10 respondents were from the age group of 26-30 and 8 respondents fell in the age group of 31-40.

Telenor is the upcoming competitor of Ufone as its target market is the youth. Our study reveals that 41 respondents in the age group of 18-25 chose Telenor as their mobile service provider in Pakistan. 6 respondents in the age group of 26-30 while only 3 respondents fell in the age group of 31-40 had Telenor as their mobile service provider.

According to the research, 19 respondents falling in the age group of 18-25 had Warid as their mobile service provider. 6 respondents in the age group of 26-30, and 7 respondents in the age group of 31-40 were 
users of Warid.

The research further showed the results of the last cellular service provider in Pakistan which is Zong. 12 respondents fell in the age group of $18-25,4$ in the age group of $26-30$, and only 1 respondent in the age group of 31-40.

Table 2

\begin{tabular}{|c|c|c|}
\hline Demographics & & $\%$ of respondents \\
\hline \multirow{2}{*}{ Gender } & Male & 53 \\
\hline & Female & 47 \\
\hline \multirow{4}{*}{ Age } & $18-25$ & 72 \\
\hline & $26-30$ & 12 \\
\hline & $31-40$ & 10 \\
\hline & 41 and above & 6 \\
\hline \multirow{5}{*}{ Education } & Matriculation & 3.8 \\
\hline & Under Graduate & 37.6 \\
\hline & Graduate & 32.7 \\
\hline & Post Graduate & 21.3 \\
\hline & Others & 4.6 \\
\hline \multirow{4}{*}{ Profession } & Business & 14.4 \\
\hline & Services & 18.6 \\
\hline & Student & 55.5 \\
\hline & Others & 11.4 \\
\hline \multirow{5}{*}{ Current Cellular Service Provider } & Mobilink & 14.1 \\
\hline & Ufone & 45.2 \\
\hline & Telenor & 19.8 \\
\hline & Warid & 14.1 \\
\hline & Zong & 6.1 \\
\hline
\end{tabular}

\subsection{Descriptives}

Table 3

Descriptive Statistics of variables

\begin{tabular}{llllll}
\hline & $\mathrm{N}$ & Minimum & Maximum & Mean & Std. Deviation \\
\hline Quality & 263 & 1.00 & 5.00 & 3.2035 & .66724 \\
Price & 263 & 1.00 & 5.00 & 3.1065 & .73916 \\
Promotions & 263 & 1.00 & 5.00 & 3.2779 & .83365 \\
Social Factors & 263 & 1.00 & 5.00 & 2.8897 & .86034 \\
Purchase Behavior & 263 & 1.00 & 5.00 & 3.0456 & .76170 \\
\hline
\end{tabular}

The results were computed for each variable. According to the descriptive analysis, minimum responses for each variable was 1 while maximum responses was 5. The descriptive statistics for the variable of quality's mean is was 3.2 and standard deviation was 0.66 which means that most of the responses were neutral. Mean of price was 3.10 while its standard deviation was 0.73 . Mean of promotions was 3.27 and its standard deviation was 0.83 . For social factors, the mean was 2.88 and the standard deviation was 0.86 . Lastly, the mean for dependent variable, purchase behavior, was 3.04 and the standard deviation was 0.76 .

\subsection{Correlation Analysis}

Correlation analysis fundamentally states about the strength and direction of variables with each other. In statistics, " $r$ " represents the Pearson correlation coefficient. It can either be used to measure the association between one independent and another independent variable or between independent with the dependent variable. It is only concerned with the strength of the relationship The relationship can either be positive or negative. If the Pearson correlation coefficient, " $r$ " is closer to -1 , it means there is a strong negative linear relationship and if it is closer 1 it means there is a strong positive linear relationship. To study the relationships between the independent variables; quality, price, promotions, and social factors with each other and with the dependent variable; purchase behavior. 
Table 4

Correlation analysis of quality, price, promotions, social factors and purchase behavior

\begin{tabular}{llllll}
\hline & Quality & Price & Promotions & Social Factors & Purchase Behavior \\
\hline Quality & 1 & & & & \\
Price & $.342^{* *}$ & 1 & & \\
Promotions & $.275^{* *}$ & $.374^{* *}$ & 1 & 1 \\
Social Factors & $.126^{*}$ & $.226^{* *}$ & $.445^{* *}$ & $.433^{* *}$ & 1 \\
Purchase Behavior & -.008 & $.137^{*}$ & $.268^{* *}$ & \\
\hline
\end{tabular}

**. Correlation is significant at the 0.01 level (2-tailed).

*. Correlation is significant at the 0.05 level (2-tailed).

Table 3 shows that how quality, price, promotions, social factors and purchase behavior are positively or negatively correlated with each other. The test indicates that there is a negative correlation between these two variables; Quality and Purchase Behavior $(\mathrm{r}=-0.008, \mathrm{p}=0.893)$, a positive relationship between Price and Purchase Behavior $(r=0.137, p=0.027)$, Promotions and Purchase Behavior $(r=0.268, p=0.000)$, and Social Factors with Purchase Behavior $(r=0.433, \mathrm{p}=0.000)$. Social Factors has the highest Pearson correlation coefficient i.e. $0.433(43 \%)$.

\subsection{Regression Analysis}

The test of the regression equation primarily explains the impact of changes in an independent variable on the dependent variable. Regression analysis predicts the values of the dependent variable based on the value of at least one independent variable, it explains the impact of changes in the independent variable on the dependent variable. In linear regression there is only one independent variable and the relationship between independent variable and dependent variable is described by a linear function and the changes in the dependent variable are assumed to be caused by the changes in the independent variable. The equation of linear regression is $y=b x+a$ where "a" is a constant, " $b$ " is the slope and " $x$ " is independent variable. Whereas if we talk about

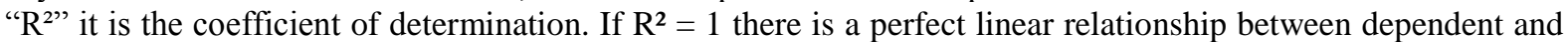
independent variables which means that there is a $100 \%$ variation exists in the dependent variable and that is because of the variation in the independent variable. If $0<\mathrm{R}^{2}<1$ there is a weak linear relationship between independent and dependent variables. Some but not all the variation in the dependent variable is explained by the variation in the independent variable. If $\mathrm{R}^{2}$ is 0 it means that there is no linear relationship between independent and dependent variable. None of the variation in dependent variable is explained by the variation in independent variable.

Table 5

Liner Regression Analysis Quality, Price, Promotions, Social Factors and Purchase Behavior

\begin{tabular}{llllllll}
\hline Variable entered & \multicolumn{2}{l}{ Coefficients } & & ANOVA & & \multicolumn{2}{c}{ Model Summary } \\
\cline { 2 - 7 } & $\beta$ & $t$ & Sig & $F(d f)$ & Sig & $R^{2}$ & Adj. $R^{2}$ \\
\hline Quality & -.009 & -.134 & .893 & .018 & .893 & .000 & -.004 \\
Price & .141 & 2.231 & .027 & 4.979 & .027 & .019 & .015 \\
Promotion & .245 & 4.489 & .000 & 20.153 & .000 & .072 & .068 \\
Social Factors & .384 & 7.769 & .000 & 60.354 & .000 & .188 & .185 \\
\hline
\end{tabular}

According to the results, $\mathrm{R}^{2}$ of quality is 0.00 which means the variation in dependent variable is not because of quality and $t$ value of quality is -. 134 which shows there is no significant effect and relationship of quality with purchase behavior.

$\mathrm{R}^{2}$ of price is 0.19 which means that there is a $1.9 \%$ variation in dependent variable is because of independent variable $\mathrm{i}$-e price whereas the $\mathrm{t}$ value is 2.231 and $\mathrm{p}$ value is 0.027 which means that there is significant relationship and impact of price on purchase behavior.

$\mathrm{R}^{2}$ of promotions is 0.072 which means there is a $7.2 \%$ variation in purchase behavior is because of promotions and the $t$ value (4.489) and $p$ value (0.000) shows that there is impact of promotion on purchase behavior.

$\mathrm{R}^{2}$ of social factors is 0.188 means there is $18.8 \%$ variation in purchase behavior is because of social factors. Social factors are the most important determinant as its impact the most on purchase behavior, $t$ value is 7.769 and $p$ value 0.000 indicate that there is significant impact of social behavior on purchase behavior 


\section{Discussions}

Under this chapter, the findings have been elaborated so as to have a better understanding of the empirical testing which was a fundamental element of this study.

\subsection{Findings}

One of the objectives of this study was to determine the factors that affect consumer purchase behavior in the cellular service sector. These determinants were identified by thorough and in-depth analysis of the literature review. Quality, price, promotions and social factors were selected wisely through literature. Negi (2009) and Santish, Kumar, Naveen, \& Jeevantham (2011) concluded in their studies that quality is one of the prime factors that affect consumer purchase behavior in Ethiopia and India. Similarly, in another developing country, Bangladesh where the study conducted by Ashaduzzaman, Sohel Ahmed, \& Khan (2011) showed that price was seen as an important determinant and motivation or demotivation for people to buy a specific mobile service provider. In a former study of Pakistan, Rajpurohit \& Vasita (2011) have concluded that low SMS rates and different packages have been a fundamental factor affecting the purchase behavior of the youth in Pakistan. Likewise, one of the variables of this study was selected by comprehending the effects of social factors, including the influence of friends and family in decision making, through the literature. A study in Ghania, West Africa concludes that the influence of friends and family in purchase decision is more than good quality service of mobile service providers (Dadzie \& Mensah, 2011). Also, in Singapore, according to Jung \& Kau (2004) consumers are highly affected and influenced by their friends and family members while selecting a mobile service provider. Another study carried out in Namibia concludes that social factors are of prime importance and is an imperative determining factor in assessing consumer purchase behavior (Kaapand, 2012). Therefore, after assessing and evaluating the essential literature the above mentioned variables were selected and used for further assessment so as to achieve the desired objectives of the study.

The study results also reveal that the choice of cellular service provider depends on the type of profession consumers adopt. People who have opted the fields of business, according to our research, mostly use Mobilink and Warid. Out of 38 total respondents who have opted business as their source of income, 11 respondents had Mobilink as their mobile service provider, 10 respondents had Warid, and 7 had Ufone while only 6 were Telenor users and 4 were Zong's. On the contrary, students mostly used Ufone; out of 146 total respondents who were students, 77 had Ufone as their mobile service provider.

With respect to price, different age groups have different opinions. The analysis shows that customers of Mobilink in the age of 18-25 are not very satisfied with the call charges charged by Mobilink whereas the Ufone customers under the same age group are highly satisfied with the call charges. Similarly, Warid and Telenor customers are also satisfied with the call charges provided but the Zong users are neither satisfied nor dissatisfied. As mentioned by Rajput, Kalhoro, \& Wasif (2012), consumers in Pakistan care less about quality but go for lower prices which is why customers of Ufone are more satisfied

When we talk about promotions, word of mouth is an imperative and dominating factor which leads to either a positive or negative purchase decision. The results show that from the age group of $18-25$, people do not like to talk much about advertisements and marketing campaigns launched by Mobilink whereas customers of Ufone, Telenor, Warid and Zong would like to talk positively about their advertisements and marketing campaigns. However, this is not the case with the age group of 26-30 who are basically business-oriented consumers of Mobilink. According to the results, they do talk positively and spread positive word of mouth about Mobilink's advertisements. Hence, the study of Jakštienè, Susnienè, \& Narbutas (2008), proves to be true in Pakistan's dynamic environment and culture as advertisements are the driving forces that lead to positive or negative purchase behavior in consumers of Pakistan.

As there is a high competition amongst different cellular service providers in offering the best and lowest rate of SMS packages, the results of this study proves how important this factor is for different age groups in deciding which mobile service provider they should choose. Evidently, it is seen that customers in the age group of 18-25 mostly agree that the offers of SMS packages motivate them to avail that service provider. Shah, et al. (2012) state that even though SMS packages have a negative impact on the youth, these packages are one of the motivators in Pakistan's youth to purchase a mobile service provider with reasonable and lower rates of SMS packages. On the contrary, most customers who fall in the age group of 25-30 have no particular interest in availing SMS packages.

Furthermore, the results of this study show that offers of free-minutes motivate female users' more than male users who have Mobilink as their mobile service provider. Whereas people having Ufone connections, the ratio of male and female users is almost equal. Consumers who have Telenor, Warid and Zong are more attracted towards offers of free-minutes specifically distinguishing males and females where males are in majority and are more attracted than females.

Also, the results indicate that whether the customers are in the age group of 18-25, 25-30 or above, they get influenced by their friends and family members when it comes to choosing their mobile service providers. 
The research conducted in Ghania by Dadzie \& Mensah (2011), also suggests that most of the people living in Ghania preferred retrieving information from friends and family before purchasing a specific mobile service provider. It is also true in the case of Namibia where the study conducted by Kaapand (2012) concludes that the majority of the population residing in Namibia have similar mobile service provider as their family and friends'. H1: Quality has a positive impact on purchase behavior. The results of this study show that there is no significant effect of quality on purchase behavior as previous study of Rajput, Kalhoro, \& Wasif (2012) also concluded that quality does not have a significant effect on purchase behavior; rather people in Pakistan are more focused on price. H2: Price has a positive impact on purchase behavior. The results of this study show that there is a significant impact of price on purchase behavior because in Pakistan price is one of the dominating and motivating factor in the purchase decision. Ashaduzzaman, Sohel Ahmed, \& Khan (2011) also state that price was one of the most important determinant and motivation or demotivation to choose a specific mobile service provider. H3: Promotions have a positive impact on purchase behavior. This study shows that promotions have a positive impact on purchase behavior as the people of Pakistan are attracted towards the promotional activities run by any service provider. Dadzie \& Mensah (2011) also conclude that promotions and word of mouth are dominating factors which affect the purchase behavior. H4: Social Factors have a positive impact on purchase behavior. The result shows that social factors are the most significant factors which have a positive impact on purchase behavior. Kaapand (2012) also states that in Namibia social factors have the most significant effect on the purchase decision of the customers.

According to the results, people under the age of 18-25 are indifferent about their expectations of service quality specifically in the cellular service sector. This is because of the impact of other variables i.e., price, promotions and social factors. The youth prefers that mobile service provider which gives them the lowest rates of calls and other value added services. Moreover, youth is more attracted towards promotions and marketing campaigns and thus spread positive word of mouth of their mobile service provider. This further creates a chain of influence, which has been represented by the variable; social factors. It has been seen through the results that most of the people living in Islamabad/Rawalpindi are influenced by their friends and family members while making a decision with respect to mobile service providers. Therefore, the Pearson correlation coefficient of social factors has the strongest positive relationship with purchase behavior.

This depicts that people residing in Islamabad/Rawalpindi do not make decisions on the basis of good or bad quality, rather they focus on price, promotions and social factors. The results of this study are in line with a former study carried out by Rajput, Kalhoro, \& Wasif (2012) which concluded that consumers of mobile service providers focus more on lower rates rather than on quality as their alternate hypothesis was also rejected.

\subsection{Contribution}

This study contributes to the literature of marketing as well as consumer behavior by examining, identifying and comprehending the theoretical framework and the dimensions that are directly associated with consumer purchase behavior. The relevant variables used in this study help understand the approach of people towards buying the services of mobile service providers. It states all the motivating, significant, and insignificant factors that either drive people to purchase a certain mobile connection or has no effect at all.

\subsection{Implications:}

The application of this study is of prime importance and can be used in other countries or in different cities of Pakistan so as to understand, comprehend and analyze the consumer purchase behavior in the cellular service sector.

\subsubsection{Academic Implication}

Thus, the results of this study contribute with the help of previous literature by examining the social as well as personal influence on purchase intention. This study can be replicated in different research settings to have better insight and knowledge about purchase behavior of consumers. The model that has been developed in this study can be adopted for future research.

\subsubsection{Managerial Implication}

The findings of this study conclude that social factors are the most dominating variable. Hence, managers must keep in mind that in order to attract and retain consumers, they must focus on social factors in their marketing campaigns and promotional activities with respect to the cellular service sector. Promotions of mobile services are another important factor affecting purchase behavior in Pakistan, managers must concentrate on creating creative, association-building and customer-focused promotional advertisements. Managers should focus on low priced packages as there is a war in price in the cellular service sector of Pakistan because of consumers of Pakistan do not concentrate on the quality but prefer low prices as they are more price conscious. 


\subsection{Limitations}

Even though this study has been carried out in an insightful and cautious manner yet some limitations exist. Data was collected only in the twin cities of Pakistan whereas there are more prospects of acumens to examine and analyze.

\subsection{Recommendations for future research}

This study was a cross sectional study whereby the data was collected only once. However, in future studies, researchers can use a longitudinal approach towards their study so as to have a better understanding of consumer purchase behavior in the cellular service sector by comparing their studies.

Apart from the variables that have been used in this study, the Big Five Model of Personality Traits can be added so as to get better insight about people, their personalities and their purchase behavior which is naturally associated with the type of personalities people have. Also, to have a better analysis of consumer purchase behavior with respect to quality, SERVQUAL can be used in future researches.

The sample of this study was limited to only the twin cities of Pakistan; Islamabad and Rawalpindi. For future studies, it is therefore recommended that the same study be carried out in different cities of Pakistan.

A comparison of post-paid and pre-paid users, their perceptions, and purchase behavior can be analyzed in future studies as that will better explain the purchase behavior of consumers in Pakistan.

\subsection{Conclusion}

The study reflects the relationships between quality, price, promotions and social factors with purchase behavior in Pakistan. There is a positive and significant relationship of all the independent variables with the dependent variable except one independent variable which is quality. The consumers of mobile service provider are not cautious about quality rather are interested in low prices, attractive advertisements and the most dominating factor are the social impact on them. The societal and cultural constraints have limited consumers in such a way that they do not care much about the service quality of mobile service providers.

Social factors as being the most dominating determinant of purchase behavior in Pakistan basically reflect the societal image of consumers. Also, they prefer buying that cellular connection which most of their friends and family use and have influence. However, consumers who are above the age of 26 are not as conscious about their image as consumers are under the age of 25 . This is because of the fact that consumers falling in the age group of 18-25 are conscious about self-image and want that particular mobile service provider with which they can create an association with.

\section{References}

[1]. Quorus Consulting Group Inc. . (2012). 2012 Cell Phone Consumer Attitudes Study. Canada: Quorus Consulting Group Inc.

[2]. Ackerberg, D. A. (1998). Advertising, Learning, and Consumer Choice in Experience Good Markets; A Structural Empiral Examination. Missouri.

[3]. Ashaduzzaman , M., Sohel Ahmed, S. M., \& Khan, M. M. (2011). CONSUMER CHOICE BEHAVIOR TOWARDS MOBILE PHONE. Journal of Arts, Science \& Commerce, 30-39.

[4]. Aydin, S., \& Ozer, G. (2005). The analysis of antecedents of customer loyalty in the Turkish mobile telecommunication market. European Journal of Marketing, 910-925.

[5]. Bowling, A. (2009). Research methods in health. Investigating health and health services. Buckinghamd: Open University Press.

[6]. Choi, S., \& Kim, M. (2007). The effectiveness of "scratch and save" promotions. Journal of Product and Brand Management, 469-472.

[7]. Dadzie, A., \& Mensah, F. B. (2011). Brand Preference for Mobile Phone Operator Services in the Cape Coast Metropolis. International Journal of Business and Management, 190-205.

[8]. Dhar, R. (1997). Consumer preference for a no-choice option. Journal of Consumer Research, 215-231.

[9]. Furaiji, F., Łatuszyńska, M., \& Wawrzyniak, A. (2012). An Empirical Study of the Factors influencing Consumer Behaviour in the Electric Appliances Market.

[10]. Hadjiphanis, L. (2011). The Effects of Advertising on Cypriot Consumer. Journal of Business Administration Online, 1-40.

[11]. Hawkins, D. I., Mothersbaugh, D. L., \& Mookerjee, A. (2010). Consumer Behavior Building Marketing Strategy (11th ed.)

[12]. Hinton, P. R., Brownlow, C., McMurray, I., \& Cozens, B. (2004). SPSS Explained. East Sussex, England: Routledge Inc.

[13]. Jakštienè, S., Susnienė, D., \& Narbutas, V. (2008). The Psychological Impact of Advertising on the Customer Behavior Communications of the IBIMA, 50-55

[14]. Johnson, B., \& Christensen, L. (2008). Educational Research: Quantitative, Qualitative and Mixed Approaches. Los Angeles: Sage Publications.

[15]. Johnson, W. C., \& Sirikit, A. (2002). Service Quality in the Thai Telecommunication industry: a tool for achieving a sustainable competitive advantage. Management Decision, 693-697.

[16]. Jung, K., \& Kau, A. K. (2004). Culture's Influence on Consumer Behaviors: Differences Among Ethnic Groups in a Multiracial Asian Country.

[17]. Kaapand, L. N. (2012). An Evaluation of Factors Determining the Selection of Mobile Telecommunications Service Providers in the Northern Region of Namibia. 3rd International Conference on Business and Ecnomic Research (3rd ICBER 2012) Proceeding, (p. 23). Namibia.

[18]. Kausar, D., Qureshi, S., Shehzad, F. A., \& Hasan, H. (2012). Factors Influencing the Customer's Satisfaction and Switching Behavior in Cellular Services of Pakistan. Interdisciplinary Journal of Research in Business.

[19]. Khan, M. A. (2010). An Empirical Assessment of Service Quality of Cellular Mobile Telephone Operators in Pakistan. Asian Social Science, 164-177. 
[20]. Kueh, K., \& Voon, B. H. (2007). Culture and Service Quality Expectations; Evidence from Generation Y consumers in Malaysia. Managing Service Quality, 656-680

[21]. Negi, R. (2009). Users' perceived service quality of mobile communications; experience from Ethiopia. International Journal of Quality and Reliability Management, 699-711.

[22]. Nelson, P. (1970). Information and Consumer Behavior. Journal of Political Economy, 311-329.

[23]. Nunnally, J. C. (1978). Psychometric Theory. New York: McGraw-Hill.

[24]. Oodan, A. P., Ward, K. E., \& Mullee, A. W. (1997). Quality of Service in Telecommunications. California: Institution of Electrical Engineers.

[25]. Oracle - ATG Web Commerce. (2011). Mobile Trends: Consumer Views of Mobile Shopping and Mobile Service Providers. USA: Oracle Corporation.

[26]. Pakistan Telecommunication Authority . (2012). Annual Report.

[27]. Pakistan Telecommunication Authority. (2011). Pakistan Telecommunication Authority: Anuual Report. Islamabad, Pakistan: PTA.

[28]. Pakola, J., Pietila, M., Svento, R., \& Karjaluoto, H. (2001). An investigation of consumer behavior in mobile phone markets in Finland. 32nd EMAC Conference, Track: New Technologies and E-Marketing.

[29]. Paulrajan, R., \& Rajkumar, H. (2011). Service Quality and Customer Preference of Cellular Mobile Service Providers. Journal of Technology Management and Innovation, 39-45.

[30]. Rajpurohit, P. R., \& Vasita, D. M. (2011). Consumer Preferences and Satisfaction towards various Mobile Phone Service Providers. Gurukul Business Review, 1-11.

[31]. Rajput, D. A., Kalhoro, S. H., \& Wasif, R. (2012). Impact of Product Price and Quality on Consumer Buying Behavior: Evidence from Pakistan. INTERDISCIPLINARY JOURNAL OF CONTEMPORARY RESEARCH IN BUSINESS, $485-496$.

[32]. Santish, M., Kumar, K. S., Naveen, K. J., \& Jeevantham, V. (2011). A Study of Consumer Switching Behavior in Cellular Service Prodider; A study with reference to Chennai. Far East Journal of Psychology and Business, 71-81.

[33]. Schiffman, L., \& Kanuk, L. (2009). Consumer Behavior. Prentice Hall.

[34]. Sekaran, U., \& Bougie, R. (2010). Research Mehtods for Business. New Delhi : Wiley India Ltd.

[35]. Sekaran, U., \& Bougie, R. (2010). Research Methods for Business; A Skill Building Approach. New Delhi: John Wily \& Sons, Ltd .

[36]. Shah, S. H., Waris, S., Aziz, J., Jaffri, A. R., Fatima, M., Ejaz, W., . . Rehman, K. U. (2012). Cellular Services Packages and and their impact on Social Values of Youth. Journal of Economics and Behavioral Studies, 204-210.

[37]. Snider, J. H. (1993). Consumers in the information age. The Futurist, 15-19.

[38]. The Express Tribune. (2012, November 21). Retrieved from PTA orders termination of late night mobile packages: Report: http://tribune.com.pk/story/469164/pta-orders-termination-of-late-night-mobile-packages-report/

[39]. Walsh, G., \& Mitchel, V.-W. (2010). The effect of customer confusion proneness on word of mouth, trust and customer satisfaction. Journal of Marketing, 838-859.

[40]. Wang, Y., \& Lo, H.-p. (2002). Service Quality, Customer Satisfaction and Behavior Intentions. Info, 50-60.

[41]. Watson, A., Viney, H., \& Schomaker, P. (2002). Consumer attitudes to utility products: a consumer behaviour perspective. Marketing Intelligence and Planning, 394-404

[42]. Witell, L., \& Lofgren, M. (2007). Classification of Quality Attributes. Managing Service Quality, 17, 54-73.

[43]. Xihao, H., Yang, J., \& Lee, H. (2007). Social Influence on Consumers Purchasing Behaviorand Related Marketing Strategy. International Journal of Mobile Communications, 319-338.

\section{INTERVIEW SCHEDULE: Purchase Behavior In Cellular Service Sector}

Students of SZABIST are conducting a research entitled. Your valuable time and information is required in this regard. All the information provided by you will be kept strictly confidential. Thank you for your cooperation.
1. $\square$ Age:
60 and above
26-30
$31-40$
41-50
51-60

2. $\square$ Gender:

$\square^{\text {Male }}$

Female

3. Education Level:

a. Matriculation

b. Undergraduate

c. Graduate

d. Postgraduate

e. Other

4. What is your profession?

a. Busines $\square$

b. Services

c. Student $\square$

d. Others

5. Which is your current cellular service provider?

a. Mobilink

b. Ufone

c. Telenor

d. Warid

e. Zong 
Note: To what extent do you agree or disagree with the following statement. Please refer the scale that has been provided.

(1: Strongly Disagree, 2: Disagree, 3: Neither Agree nor Disagree, 4: Agree, 5: Strongly Agree

\begin{tabular}{|c|c|c|c|c|c|c|}
\hline \multicolumn{7}{|c|}{ QUALITY } \\
\hline 1 & Quality of connection coverage is reliable & 1 & 2 & 3 & 4 & 5 \\
\hline 2 & Quality of signal strength is stable & 1 & 2 & 3 & 4 & 5 \\
\hline 3 & My telecom operator is very good at handling complaints & 1 & 2 & 3 & 4 & 5 \\
\hline 4 & Services offered by telecom operator are consistently good & 1 & 2 & 3 & 4 & 5 \\
\hline 5 & Service quality is exactly what I expected & 1 & 2 & 3 & 4 & 5 \\
\hline 6 & I face network connection problem while travelling & 1 & 2 & 3 & 4 & 5 \\
\hline 7 & $\begin{array}{l}\text { I face network connectivity problem in the suburbs near } \\
\text { Islamabad/Rawalpindi }\end{array}$ & 1 & 2 & 3 & 4 & 5 \\
\hline \multicolumn{7}{|c|}{ PRICE } \\
\hline 8 & I am content with the call charges charged by my telecom operator & 1 & 2 & 3 & 4 & 5 \\
\hline 9 & Availability of reasonable offers motivate me to avail those offers & 1 & 2 & 3 & 4 & 5 \\
\hline 10 & I think my telecom service provider is not really expensive & 1 & 2 & 3 & 4 & 5 \\
\hline 11 & $\begin{array}{l}\text { If the prices of the services increase I may switch/change my telecom } \\
\text { operator }\end{array}$ & 1 & 2 & 3 & 4 & 5 \\
\hline \multicolumn{7}{|c|}{ PROMOTIONS } \\
\hline 12 & $\begin{array}{l}\text { I would say positive things about the advertisements running by my telecom } \\
\text { service provider }\end{array}$ & 1 & 2 & 3 & 4 & 5 \\
\hline 13 & Print media advertisements attract me to avail the services & 1 & 2 & 3 & 4 & 5 \\
\hline 14 & Electronic media advertisements attract me to avail the services & 1 & 2 & 3 & 4 & 5 \\
\hline 15 & Offers of SMS bundle motivate me to avail the services & 1 & 2 & 3 & 4 & 5 \\
\hline 16 & Offers of free minutes motivate me to avail the services & 1 & 2 & 3 & 4 & 5 \\
\hline \multicolumn{7}{|c|}{ SOCIAL FACTORS } \\
\hline 18 & My peers have a significant influence on my purchase decision & 1 & 2 & 3 & 4 & 5 \\
\hline 19 & $\begin{array}{l}\text { To keep up with the social status in my surroundings I chose my current } \\
\text { telecom operator }\end{array}$ & 1 & 2 & 3 & 4 & 5 \\
\hline 20 & $\begin{array}{l}\text { The attractive adds and inspiring people in it influence my purchase } \\
\text { decision }\end{array}$ & 1 & 2 & 3 & 4 & 5 \\
\hline 21 & $\begin{array}{l}\text { Choosing my current service provider helps me show who I am (business } \\
\text { man, professional, youngster etc) }\end{array}$ & 1 & 2 & 3 & 4 & 5 \\
\hline \multicolumn{7}{|c|}{ PURCHASE BEHAVIOR } \\
\hline 22 & $\begin{array}{l}\text { I will switch to other telecom service provider if its prices are lower than my } \\
\text { current telecom service provider }\end{array}$ & 1 & 2 & 3 & 4 & 5 \\
\hline 23 & $\begin{array}{l}\text { I have had problems with my current telecom operator which makes me want } \\
\text { to change my telecom operator }\end{array}$ & 1 & 2 & 3 & 4 & 5 \\
\hline 24 & $\begin{array}{l}\text { Packages that are provided by telecom service providers influence my } \\
\text { purchase decision }\end{array}$ & 1 & 2 & 3 & 4 & 5 \\
\hline 25 & Better advertisements attract me in availing services & 1 & 2 & 3 & 4 & 5 \\
\hline 26 & I will choose that telecom service provider which most of my friends use & 1 & 2 & 3 & 4 & 5 \\
\hline 27 & Because of no call drops I chose my current telecom operator & 1 & 2 & 3 & 4 & 5 \\
\hline
\end{tabular}

